PROBLEMS

OF EDUCATION IN THE $21^{\text {st }}$ CENTURY Vol. 79 , No. 6, 2021

838

\author{
Michal Černý \\ Masaryk university, Czech Republic \\ E-mail: mcerny@phil.muni.cz
}

\begin{abstract}
Over the last thirty years, technology has created a new space (cyberspace) where people meet each other, seek information, or simply try to navigate through. However, there is no consensus in research on the character of cyberspaces and the extent to which they are real. In the first systematic empirical research of this nature, the study found an answer to this question through a survey of metaphorical accounts of university students in Information Studies, and Librarianship (N=102) collected over three years (20192021). Cyberspace is a real space in students' experiences, language, and thought structures. A space that allows movement, orientation, and search to be related with one another. An environment in which cognition, learning, and knowledge are structuring activities. Learning and cognition in this space occur differently than in the physical environment, which poses a challenge for developing specific didactic practices and social programs for students. Students perceive cyberspace as linked to the need to acquire new epistemic tools to help them overcome the crisis of knowledge they experience through this space. Keywords: cyberspace, didactic practices, information literacy, metaphors, pragmatism, tacit knowledge, on life
\end{abstract}

\title{
Introduction
}

Cyberspace has become a metaphor or concept that is quite common in teacher and student speech. In the online environment, students have fun (Cholifah et al. 2020; Okada \& Sheehy, 2020), experience social interactions (Lasfeto \& Ulfa, 2020), communicate (Tang \& Hew, 2020), shop, and also learn. Soffer and Nachmias (2018) argue that students perceive the online environment as a place for them associated with the role of autonomy and self-control (Carter et al., 2020) rather than face-to-face courses. Other studies (Rodriguez et al., 2008; Young \& Norgard, 2006) emphasise the dimension of a high degree of control over the research or, conversely, the lack of social interactions (Mazzolini \& Maddison, 2007), which reduce their ability to understanding concepts or authentic learning.

All these considerations of cyberspace as a learning environment are essential for designing any online learning activity. This research focuses on how students think about cyberspace, what it is for them, and how they characterise it. A deeper understanding of this issue can lead to significant progress in the design and implementation of online learning (Hattingh et al., 2020) or even blended learning (Rasheed et al., 2020) courses.

\section{Definition of Cyberspace}

Defining the concept of cyberspace is complex. The term is said to have first been used by William Gibson in 1984 in his sci-fi Neuromancer (Concannon, 1998; Punday, 2000). Gibson (1995) speaks of it as "a metaphor that gives us to grasp this place where, since the Second World War, more and more things have been created and are being created that we perceive 
today as part of our culture... It's beneficial for everyone involved because there is only a movement of data in it." (Gibson, 1995) However, this first use of cyberspace is questioned (Stratton, 2013).

Lessig (1996) states "cyberspace is a place. People live there. They experience all the sorts of things that they experience in real space there. For some, they experience more. They experience this not as isolated individuals, playing some high-tech computer game; they experience it in groups, in communities, among strangers, among people they come to know, and sometimes like." Ellis et al. (2004) agree with this concept, emphasising the realisation aspect of life from community sociology (Fernback \& Thompson, 1995) in this environment. In this context, digital anthropology (Horst \& Miller, 2020), sociology (Marres, 2017; Selwyn, 2019), and specific digital ethnographic methodological approaches (Murthy, 2008; Pink et al., 2015; Varis, 2016) are increasingly being promoted. Mayer offers a more technical approach when he emphasises that it is an electromagnetic environment whose purpose is to "create, store, modify, exchange, share, acquire, use or delete information" (Mayer et al., 2014).

Research finds us in a situation where, on the one hand, there is no single discourse defining cyberspace (Mayer et al., 2014; Ottis \& Lorents, 2010). It is systematically examined as a social world in which social science research methods can be used. The increased number of documents dealing with cyberspace are shown in Figure 1, but to say that are in an interesting research space, the study of which corresponds well to current trends - on methodological and empirical studies (O'Connor \& Madge, 2003 Stokrocki, 2007) and also theoretical (Boehlefeld, 1996, Floridi, 2011, 2013).

\section{Figure 1}

Increase in Documents in the Scopus Database when Searching for "Cyberspace" in 19902020.

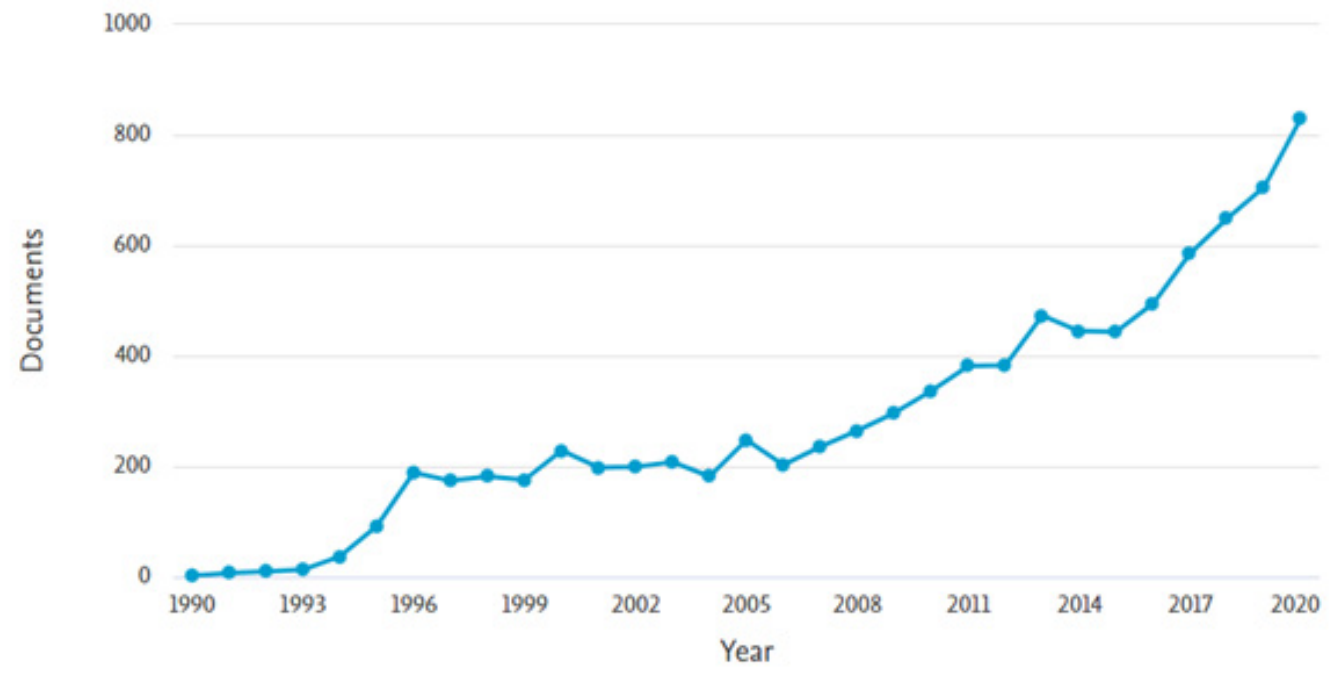

Note: Data for the last year may increase as more documents are indexed (the figure was created on July 31, 2021). 
Michal ČERNÝ. Cyberspace as a space: Analysis of metaphorical statements of university students

PROBLEMS

OF EDUCATION

IN THE $21^{\text {st }}$ CENTURY Vol. 79, No. 6,2021

840

\section{The Space construction in Pragmatism and Social Constructivism}

Cohen (2007) defines himself against the metaphor of cyberspace as space. He argues that people understand "ordinary" space in a different way and that the use of the metaphor of "space" about "cyberspace" leads to a misunderstanding of this entity. According to him, space is a matter of embodied structure, which no online environment can replace. For him, cyberspace is constructed by interactions, dynamic changes and perceptions, which, however, does not correspond to the common psychology of space, thus continuing the work of Johnson (2017) and his concept of experiential realism. Kolko et al. (2013) describe cyberspace as an environment composed of zeros and ones. Like something that doesn't know shades of grey or any in between. This explicit discretion of the environment thus understood leads to the fact that people cannot speak of orbital space. This is even though social interactions are realised in this environment.

The pragmatic approach is based on Lakoff's (1988) argument that space is what structures are meant for meaning creation. This claim is supported by research in the field of immersive virtual reality (Ryan, 2015; Walsh \& Pawlowski, 2002 examining the structure of concepts during learning (Johnson-Glenberg et al., 2016; Lindgren et al., 2016). The structuring of ideas is different in the classroom, and the online environment is well researched in different settings and age groups (Arrosagaray et al., 2019; Furió et al., 2019; Smart \& Cappel, 2006; Smith, 2010), 2017) argues that it is the environment and the interactions within it (as opposed to Cohen (2007) emphasising the constitutional nature of interactions) that make it possible to create meaning and thought.

The second approach is based on the social construction of reality (Berger \& Luckmann, 1966), emphasising that reality is not a question of objective measurement but social interactions. Through values, language, institutions and social principles, society shapes what one knows in the world. If research work with these starting points, they can say that cyberspace is undoubtedly space (Kalinkin, 2015) because it is a place of construction of knowledge and social or power structures (Holmes, 1997; Walmsley, 2000).

\section{Literature Background}

The research subject is the analysis of how students of librarianship and information studies talk about cyberspace and the metaphors they use to describe it. Working with metaphors and metaphorical statements is a method used in pedagogical research (Fábián, 2013; Haskins, 1989; Leino \& Drakenberg, 1993; Lynch \& Fisher-Ari, 2017; Švec et al., 2016).

Cyberspace itself and the social and information interactions represent an important area of various research (Gálik, 2017; Ghasemi Varjani Iran, 2019; Nyinkeu et al., 2018), including those that focus on its definition in partial aspects (Betz, 2017; Taddeo, 2018). Specifically, cyberspace's structure, properties, and spatiality are discussed (Ning et al., 2018; Saracco, 2019; de Varela, 2018).

Therefore, the research gap that will be filled by this research combines these two areas of interest. When cyberspace is referred to as a metaphor (Adams, 1997; Cohen, 2007; Olson, 2005; Wolfe, 2001) it is as a theoretical study, meaning that it will be essential that the empirical aspect of the construction of this metaphor is followed.

The methodological inspiration for our research was the work of pragmatist philosophers and linguists Johnson $(2007,2017)$ and Lakoff $(1988)$, but above all, their joint work (Lakoff \& Johnson, 1980, 1980a, 1983). The basic idea is that metaphors are not just an ornament of language, something purely literary-poetic, rather that they are an image of thinking formed in concrete experiences with the environment. Human corporeality, the community in which they live and the environment in which it moves all contribute to building a language based on 
metaphors. Thus, metaphors allow us to reconstruct the structure of concepts, the reasons for understanding certain phenomena, including those that are not readily apparent at first glance (Lakoff, 1988).

Understanding metaphors associated with cyberspace is a way to understand how learning in cyberspace occurs or how to think about it. If it turns out to be an inadequate metaphor and students, do not work with cyberspace as with space, then given the Lakoff study, it should be indifferent whether taught online or in physical space. Educational technology is essential only as a means of education aimed at greater clarity, entertainment (Pienimäki et al., 2021), multimedia (Wah, 2007), deeper immersion into issues (Snape, 2011) or interactivity (Palmárová \& Lovászová, 2012; Sherron \& Boettcher, 1997). However, if cyberspace is a natural space for students to structure their knowledge (Johnson, 2017; Lakoff \& Johnson, 1983), then it means possibilities in the design of different learning environments that will lead to different understandings, perceptions and structuring of knowledge (Johnson, 2017; Glenberg et al., 2016; Lindgren et al., 2016).

\section{Research Question}

How do students of information studies and librarianship view cyberspace and does it have a spatial characteristic for them?

This question underlies a broader discussion about the characteristics of cyberspace in general (Cohen, 2007; Dodge \& Kitchin, 2003; Kolko et al., 2013; Lemley, 2003), but also especially in the field of education (Johnson-Glenberg et al., 2016). Johnson-Glenberg et al. answer may be essential for practical teaching because, according to Lakoff (1988), experience from different backgrounds leads to different structuring of concepts and building different ways of looking at a problem. Understanding how students work with a virtual environment at the level of their experience has specific educational implications (Lindgren et al., 2016).

\section{Research Methodology}

\section{Background}

Research into various societal phenomena through conceptual metaphors is gradually becoming a common methodological approach (Coulson \& Cánovas, 2009; Kövecses, 2016; Landau, 20016), although there are disputes about the ways and possibilities of defining metaphors precisely (Casasanto, 2009; Gibbs, 2009; Kövecses, 2008). Applications of this method can also be seen in education (Bailey, 2003; Daane, 2018; Śvec, 2004). Research continues this tradition, and it will also focus our research on students and their formation of experiences or metaphors that they will use in their descriptions.

The aim of metaphor analysis is not to describe only the metaphors themselves but to reveal the concepts they relate to in everyday language based on their identification. Metaphor is thus a visible form of the world's inner, dynamically shaped idea (Lakoff \& Johnson, 1983). A metaphor is a means of understanding the experience of the one who uses it.

Commonly, metaphor research is combined with clean language interviews to collect data from respondents in order to reduce the introduction of specific terms or concepts into respondents' statements. The research is unusual in this respect because it works with written text and its analysis. The students provided their statements in written form, which should have been around 500 characters in length, including spaces. Thus, for each year of research, a dataset of responses was created for further analysis.

In order to eliminate the possibility of students responding to any current stimuli, events or current cultural context that might bring a certain kind of metaphorical utterances into their

$\mid$\begin{tabular}{l} 
PROBLEMS \\
OF EDUCATION \\
IN THE 21 $21^{\text {st }}$ CENTURY \\
Vol. 79, No. 6, 2021 \\
\hline 841
\end{tabular} 
Michal ČERNÝ. Cyberspace as a space: Analysis of metaphorical statements of university students

PROBLEMS

OF EDUCATION

IN THE $21^{\text {st }}$ CENTURY Vol. 79, No. 6,202

842

speech, the research was conducted in three consecutive years. As Figure 3 shows, the essential metaphors for our research are stable over time.

In total, the research collected 102 student testimonies. The length of the answers varied, the recommended range was 500 characters, including spaces, but in reality, the answers ranged between 107-1174 characters.

Working with metaphors in text is not methodologically impermissible and is used, for example, by Lakoff and Johnson (1983). While most metaphor research works with a relatively limited sample of respondents because it must qualitatively analyse responses and code individual conversations (narrative codes were used to describe the qualitative data in datasets; an overview of the most frequently used codes with their explanations is given in Table 2), the procedure in this research could have been faster and more efficient. Experience with structuring topics from previous research was used in the data processing. The students' texts were easily searchable. This allowed the number of students to be significantly higher and allowed us to work with 102 responses.

\section{Sample Characteristics}

For the research, bachelor's students of librarianship and information studies (LIS), who are studying in the first year of the bachelor's study program in the second (Spring) semester, and one group of students in the second year or the third (Autumn) semester, were used. The change of study accreditation forced the year change, but both groups are in an almost identical phase of their university preparation.

The following notation to mark the answers in the next chapter is used: A9 for answers of students from the semester Autumn 2020 (students of the 3rd semester), S0 for students from the semester Spring 2020 and S1 for students from the semester Spring 2021 (students of the second semester). The number of responses is between 30-39, corresponding to a specific population distribution stability.

Students completed a course focused on digital competencies, constructed according to the DigComp competency framework (Carretero et al., 2017). At the end of it, they filled out a reflective questionnaire, from which came the answers in this research. The number of responses and the return is given in table 1 . The answers are treated as anonymous, and with a return rate of $47-70 \%$. The exact ratio of women and men could not be determined. Across the study, approximately $20 \%$ are men and $80 \%$ are women, and a similar distribution can be expected for the responses analysed.

Table 1

Code Designation, Sample Size and Return in Individual Datasets

\begin{tabular}{lcc}
\hline Semester/Designation & Analysed answers & Return [\%] \\
\hline Autumn 2019 / A9 & 39 & 70 \\
\hline Spring 2020 / S0 & 30 & 47 \\
\hline Spring 2021 / S1 & 33 & 50 \\
\hline
\end{tabular}

\section{Data Collection}

Students answered a more comprehensive reflective questionnaire with some questions, the first of which was "How do you imagine a digitally competent person?". Because research works with metaphors, it was necessary to choose a question that will not lexically encourage 
students to use words such as space, orientation, movement, environment, etc., but allow them to be part of their grasp of the idea of the world.

Students submitted the file in docx, doc, odt or pdf formats to the university's information system. The data were downloaded, converted into one file in docx format, and then the answers to only the first question were selected. Such datasets were created for all three periods and were subsequently imported for the Atlas.ti program (a computer program for qualitative data processing, coding and analysis), in which the data analysis took place.

\section{Data Processing}

Data processing used the Atlas.ti tool for data processing, which is used for processing qualitative data. Research used preliminary research (Černý, 2020) from data from 2019, which was published separately. There is a good idea of what basic concepts and thought structures research wants to look for in the text. The research itself is theoretically anchored in pragmatist theories (Johnson 2007, 2017; Lakoff 1988; Lakoff \& Johnson, 1983) which allowed us to focus on metaphors related to movement as a fundamental element structuring the understanding of space (Lakoff \& Johnson, 1983). Looking at table 2, it can be seen that the most important categories are based on a pragmatist understanding of metaphorical expression (Lakoff $\&$ Johnson, 1983).

The research design is shown in Figure 2. The first data collection took place in the autumn of 2019 as part of another research project. It soon became clear that there were spatial metaphors in the students' accounts that would be interesting to explore further. Based on this consideration, open coding of this dataset was carried out, and the first results were published (Černý, 2020). A more careful analysis of the data identified key concepts that would be interesting to pursue further: orientation in space, description of the environment, orientation in space, feeling safe, critical thinking, use of some skills or elements in space, reflections on the nature of the environment. These findings served to identify the core concepts to be investigated in the following years of the research.

Two data collections followed (Spring 2020, Spring 2021). These produced two datasets that were further analysed using open coding (the most common codes are shown in Table 2). In total, 34 codes were used that were related to the issue of cyberspace and its characteristics. These 34 codes were used for one more dataset analysis. This produced the quantity of code uses seen in Table 2.

From 34 codes, the four most important categories (in terms of the research question and stability in the datasets) can be seen in Table 3. Subsequently, the individual tagged statements by category were exported and analysed.

The research then created a concept of cyberspace as a space in the students' understanding (language accessed through metaphors). This section combines both the research data and the literature on the topic, which we draw on in the Introduction section.

In the results, statements of individual students are not indicated, only state what semester they are from. Each notice is stated at most once. 
PROBLEMS

OF EDUCATION IN THE $21^{\text {st }}$ CENTURY Vol. 79, No. 6,2021

844

Figure 2

Research Workflow Diagram

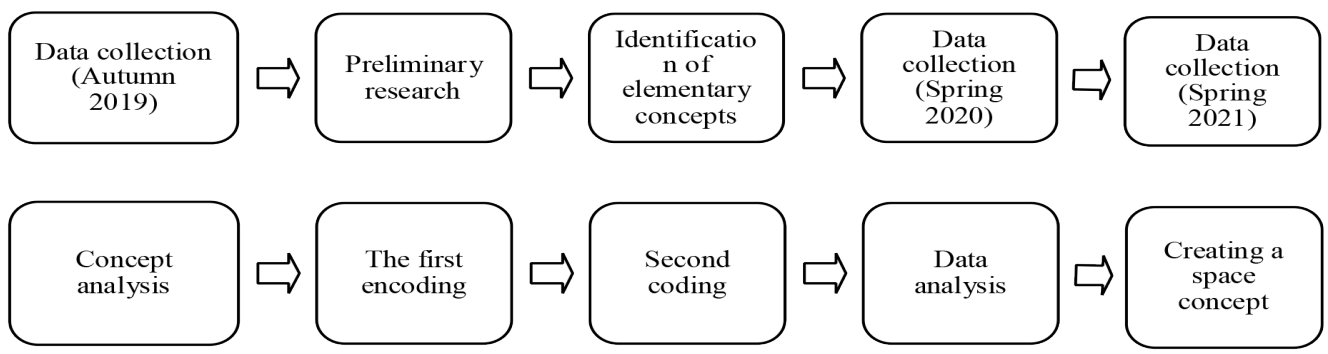

Research Limits and Ethics

A limitation of research may be that metaphor analysis is typically used for longer speech acts combined with the pure language method or broader lexical analysis. The study only worked with short (107-1174 characters) answers, reducing the richness and structure of individual metaphors. On the other hand, research gets only strong metaphors that are important for the respondents. In the interviews, the respondent's researcher asks about metaphors, which is not possible here.

The second limit is the small return on data, although the average return on a classic questionnaire is $57 \%$, is not considered low. But it would be undoubtedly helpful to know the insights of those who did not complete the questionnaire. The last limit to mention is the coding performed by one person; coding in more people could bring some more information.

The challenge for future researchers is to extend analysis to other parts of the population so that it is possible to talk about students in general or a specific broader view. At the same time, however, must be remembered that analysis is primarily qualitative. It looks at new topics and understandings of reality, not its relative representation in the population.

From the point of view of research ethics, the anonymity of data needs to be addressed. This is because only parts of the answers are used, translated from Czech and Slovak into English, making it impossible to identify a specific speaker. The anonymised designation of students is not mentioned, but only the semester in which they studied. Students were informed about the research and had the opportunity not to submit answers.

\section{Research Results}

The results are qualitatively described and analysed. Although this research is qualitatively focused, there are some essential quantitative characteristics to the answers. For the analysis, 34 codes were used, of which the most frequent are listed in table 2. 
Table 2

The Most Frequent Codes and their Definitions

\begin{tabular}{lcl}
\hline Code & Frequency & Description \\
\hline Search & 44 & $\begin{array}{l}\text { Statements related to information retrieval, finding, evaluation of } \\
\text { information about finding and obtaining it. }\end{array}$ \\
\hline Environment & 36 & $\begin{array}{l}\text { Statements relating to describing an environment with certain } \\
\text { characteristics or a specific world (digital, technological). }\end{array}$ \\
\hline Use & 34 & $\begin{array}{l}\text { Statements focused on practical and helpful handling, manipulation, and } \\
\text { the digital environment, objects in it, and achieving one's own goals. }\end{array}$ \\
\hline Orientation & 32 & $\begin{array}{l}\text { Statements focus on the concept of orientation in various lexical } \\
\text { meanings and on the structuring of implications or movement in } \\
\text { cyberspace. }\end{array}$ \\
\hline Safety & 25 & $\begin{array}{l}\text { Statements related to the concepts of security, data protection, danger, } \\
\text { threat, risk. }\end{array}$ \\
\hline Critical thinking & 19 & $\begin{array}{l}\text { Statements lexically fixed to the concept of "critical thinking" and related } \\
\text { to it (critical evaluation, assessment, etc.). }\end{array}$ \\
\hline Space & 15 & $\begin{array}{l}\text { Statements reflecting the digital environment, cyberspace or the Internet } \\
\text { as a specific form of space. }\end{array}$ \\
\hline Work and personal life & 14 & $\begin{array}{l}\text { Statements focused on laughing at the boundaries between work and } \\
\text { personal (study life), closely related to digital technologies. }\end{array}$ \\
\hline
\end{tabular}

An important topic is data stability. Even if a qualitative line were followed, it would be possible that a particular group of users would be influenced, for example, by a shared experience, educational approach, or cultural phenomenon, which would create a character of a specific emergency. However, the data shown in table 3 and figure 3 indicate considerable stability of the data in the codes (after normalisation) in terms of primary treatment of the topic. Thus, it can be concluded that the collected answers correspond - at least in part - to a particular social opinion within the studied cohort of students.

Table 3 shows the most important codes and their density in datasets. Since the datasets are not the same size year after year, a normalization process was chosen. The numbers in the table then correspond to the formula: (number of specific code occurrences in the dataset)/ (number of analysed statements in the dataset).

Table 3

Relative Frequencies of the Most Critical Codes after Normalisation

\begin{tabular}{lccc}
\hline & Autumn 2019 & Spring 2021 & Spring 2020 \\
\hline $\begin{array}{l}\text { Space } \\
N=15\end{array}$ & 0.05 & 0.24 & 0.17 \\
\hline $\begin{array}{l}\text { Environment } \\
N=36\end{array}$ & 0.26 & 0.48 & 0.33 \\
\hline $\begin{array}{l}\text { Search } \\
N=44\end{array}$ & 0.41 & 0.36 & 0.50 \\
\hline $\begin{array}{l}\text { Orientation } \\
N=32\end{array}$ & 0.33 & 0.15 & 0.47 \\
\hline
\end{tabular}

Note: Data is rounded to two decimal places. $N$ corresponds to the number of code occurrences in all datasets 
Michal ČERNÝ. Cyberspace as a space: Analysis of metaphorical statements of university students

PROBLEMS

OF EDUCATION

IN THE $21^{\text {st }}$ CENTURY

Vol. 79, No. 6,2021

846

The graph shows the normalised distribution of selected codes. All four terms are present in the students' statements in the three semesters examined, indicating the data's stability.

\section{Figure 3}

Representation of the Most Frequent Spatial Metaphors in Datasets

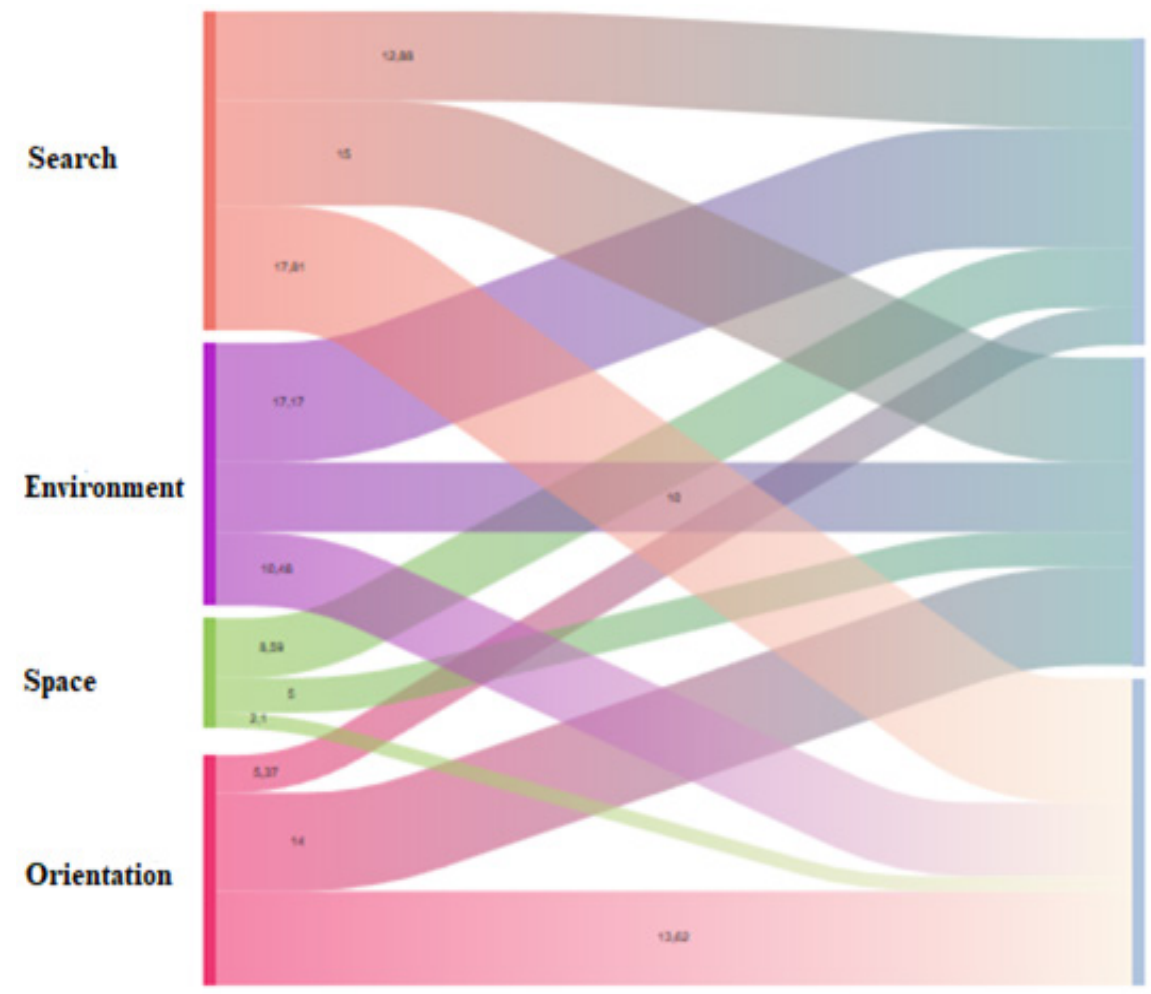

Spring 2021

Spring 2022

Autumn 2019

Suppose Atlas.ti were used to select four key terms and create a frequency-oriented word cloud. In that case, the following would be identified as the most important words related to this issue: information (44), digital (30), can (30), can (26), search 24, human (21), environment (19), able (16). These terms most often occur in metaphors characterising cyberspace.

In this part, qualitative knowledge from students' answers is integrated with a thematic analysis, which allows for division into sub-areas and sub-topics, which are then placed in a broader context in the discussion. The notation established in Table 1 is used to identify the statements made by year (A9, S0 and $\mathrm{S} 1)$.

\section{Space as the Phenomenon}

Cyberspace is mentioned only once: "security in cyberspace and addressing the various issues involved" (A9). More common are phrases such as the digital world: "A person who knows that there are various attacks in the digital world" (S1) or "knows what to look out for in the digital world" ( $\mathrm{S} 0$ ), who has a specific ontological quality: "the digital world it survives and is not overwhelmed by the digital pitfalls that are all around us" ( $\mathrm{S} 0)$ and certain entities can be placed in it "One can add one's work to the Internet" (S1).

These statements refer to the fact that students think of cyberspace as an independent world in which the metaphor of a vessel can be applied; it is a structure in which there is movement and orientation, as will be discussed below, which has specific ontological characteristics. 
Interestingly, even in these examples, it is often associated with danger, one of the two most

common discourses, along with usefulness.

\section{Space as a Place of Movement}

The fundamental characteristic of space is that movement is possible in it. "The ability to move as safely as possible on the Internet" (A9) or "can move safely in the digital environment" (S1). During this movement, he realises his will "this person should move on the Internet within his needs" (A9, S0) or "the skill required is the ability to move as safely as possible on the Internet" (S0).

Information on the Internet can be accessed "accesses information found on social networks with a healthy dose of scepticism" (S0) or predict movement and interaction in such a space "Can anticipate the risks associated with movement on the Internet" (S0). Movement can also be aesthetic and meaningful "approach digital technologies and can use them elegantly and meaningfully" (S0) or lead to "encountering a problem" (S1).

Encounters with objects can have the character of searching and finding: "in my opinion, a digitally literate person should be able, at least to a certain extent, to find the necessary information himself and be able to evaluate it." (A9) or "the digitally literate person can find a relevant source of information according to his need, also evaluate it in terms of truthfulness and completeness, then use it meaningfully" (A9) or "manages to find the necessary information" (S1).

All these quotes show the essential characteristics of cyberspace - it is characterised as a space in which movement is possible, which can lead to aesthetic, practical or other activities. It can be predicted that movement is a means to achieve will or goals. This is important because this characteristic is an essential dimension of normal human movement. This intentionality in finding in use is not objectivist. Still, it emphasises the personal need of the individual and the conformity of the information found with the truth so that he can "judge the truth and usefulness of the content found" (S1).

\section{Space and Orientation}

For the movement to be an expression of will, it must be possible to orient oneself in space, to have the opportunity to decide which direction to go in it and how to structure it. Only a space can be structured in which human has an orientation when one knows, as Lakoff and Johnson (1983) emphasise, what is near and far, where it is up and down, how things are arranged according to each other.

"Orientation in the world of digital technologies should be at the very core of the skills of the digital literate person." (A9). It shows that there is a world of digital technologies in which it is necessary to orient oneself. Similarly, "a digitally literate person can orient himself in digital technologies and who can use these technologies" (A9) puts into context the orientation and the possibility of using parts of this space. "I would probably describe it as an orientation in possibilities" (A9). It refers to the combination of orientation and the possibility to act.

"As a person who can orient himself in the digital environment and understands it" (S1) connects the concept of orientation and understanding. Students orient them only where there is an understanding of the framework within which they form order. "He can orient himself in the flood of resources. He can detect the poor and select them effectively" (S1) shows both the spatial character of cyberspace and orientation in it, as well as its dynamics, and above all, the possibility of man to change this world. Likewise, "the digitally literate person is not only oriented in the digital world but is also capable of independent activity" (A9) puts the possibility of orientation and activity in close connection. 
Michal ČERNÝ. Cyberspace as a space: Analysis of metaphorical statements of university students

PROBLEMS

OF EDUCATION

IN THE $21^{\text {st }}$ CENTURY Vol. 79, No. 6,202

848

This orientation permeates the online and offline worlds and forms one complex phenomenon "able to orientate themselves in them and also use their full potential and involve them in their daily lives" (S0), as shown below, it used as an activity of these two worlds strongly connected in student statements.

"He should be able to look at information critically and be able to search for the necessary information (also use advanced search methods). It should have an overview." (S0). It offers two vital aspects; it connects thinking and searching into one whole, which leads to the goal of orientation, namely, to gain an overview. Both over space and objects or tools in it "have at least a basic overview of which tool can be used to work with different types of documents, photos, etc." (S0).

\section{Search}

Specific students, of course, talk about search as an essential competence. It is vital for us to connect search with the concept of cyberspace as such. Searching is related to the truth of what students know. Not everything that is presented to people online is true. "Can critically assess which information on a website is relevant and credible when searching the Internet" (A9), "he should be able to look at information critically and be able to search for the information he needs (using advanced search methods as well)" (A9), "one can search for information and assess its truthfulness and usefulness" (S1) or synthesise: "one can search for it, verify sources and search for the most relevant ones, one can correctly process, organise and then use information".

Thus, the search for students is related to the evaluation. Therefore, a particular crisis of knowledge or post-factual time that students experience is treated with an emphasis on critical thinking and judgment. The above-accentuated orientation is the result of this critical analysis. This is even though, for some, searching is finding: "it manages to find information" (S0).

Searching is not aimless, but it is a process leading to the structuring of the meaning "can not only search for all the necessary information but also work with it properly" (S1). This everyday work is a prerequisite for usefulness. "Can search for them, verify sources and find the most relevant ones, can process information correctly, organise and then use it" (S1) or "I imagine a digitally literate person as someone who can constructively search for information, critically assess it and further evaluate it."

From the selected excerpts, it is also clear that the search is not a random process but something one should master or learn. This research does not approach cyberspace naively without prior training, but it is only through learning that there is an extensive possibility of manipulating this space. "Is willing to learn new skills and seek new services, resources and information" (A9).

\section{Usefulness and Connectivity}

The search leads to structuring a world whose goal is usefulness, a certain possibility of benefit for oneself or others. Students will understand it used as a basic model of manipulating the world, its activating concept.

"For me, a digitally literate person is a person who uses technology every day for personal or work matters and can use it without the slightest difficulty" (S0), "by interacting with information and communication technologies, he should be able to fulfil his personal, work, or, for example, study needs." (A9) or "has certain skills and knowledge with which he can use digital technologies safely and meaningfully in his life, whether in learning, at work or in his free time." (A9). These quotations show that cyberspace is not just a particular metaphorical place or state. Still, something that allows saturating the needs of people is a 
place of utility, i.e., in the pragmatic sense. It fulfils the primary condition for the meaning of its existence.

Usefulness is not only selfish, not a means of fulfilling one's own needs, but also a place to care for others. "A digitally literate person is a valuable member of society and a citizen of the state." (S1) and "Moves the other forward as his assistant" (A9). So, it is not a space of loneliness but a socially shared field in which being with others is an important topic. From the perspective of the social construction of reality, this dimension is essential, or students reflect that their world is made up of others and responsible for it.

The utility is at the same time a bolt of the online and offline world. "He engages his abilities both in the Internet environment and in the ordinary." (A9), "in this case, modern technology can make our lives easier with its functions and speed." (A9). Usefulness not only connects the two worlds but extends the dimension of everyday life. Cyberspace is not an extraordinary world that they enter once in a while, but it shapes, simplifies and threatens everyday life. It thus becomes the environment that shapes thinking and the structure of the world.

\section{Environment and Resource}

The characteristic of cyberspace is not only as space but also as the environment and means, i.e., to its deeper ontological aspects. "In the digital environment, he consciously handles according to his preferences and possibilities" (A9) is a statement showing that students are faced with a specific structure, within which one experiences both possibilities (given his previous experience or skills) and opportunities of a sure will.

"He can take advantage of both the benefits of the Internet environment and at the same time be able to understand the new dangers that are in this environment and can protect or even prevent them." (A9). Reports that this digital environment leads to a new understanding, meaning formation. "He can cope with the changing environment and nature of activities, to work effectively with every new digital technology without losing his social identity" (S1). Continues Lakoff's argumentative structure - reflected experience with this environment.

This environment can be dangerous. Its various parts "furthermore, it effectively solves various tasks with the help of tools and selects a suitable online environment for cooperation with others." (A9). Success in it depends on the reflection of one's own experience "the use of acquired experience is an essential part of it" (S0).

Cyberspace is not just an environment, but also a means "can perform tasks on a computer-based on its skills but does not use it as a one-sided tool" (S1), "It should be able to use some means of sharing and communicating information." (S1), that can be used to change the environment in which they live, or even ourselves, "uses modern technology for its improvement" (S0), which overcomes the digital-analogue barrier.

\section{Compliance with the Truth}

Students' attitude towards cognition in cyberspace is sceptical. They emphasise the need to reflect on the integrity of information "it should also recognise its relevance and veracity." (A9), "be able to distinguish (at least most likely) true information from misinformation." (A9).

The reason for scepticism is the fullness of the Internet of misinformation, but also of the fact that the information found influences "one should not be influenced by unverified or false information" (A9) or "Can distinguish objective, fact-offering articles from articles manipulating emotions" (A9). Every information interaction leads to a change in behaviour and thinking, so it is true of a digitally competent person that "in the digital field, he behaves safely and can distinguish the credibility of information." (S0) 
Michal ČERNÝ. Cyberspace as a space: Analysis of metaphorical statements of university students

PROBLEMS

OF EDUCATION

IN THE $21^{\text {st }}$ CENTURY Vol. 79, No. 6,2021

850

The path is probably Descartes' critical thinking, to which the answers repeatedly return. "Using these technologies, a literate person applies critical thinking and is aware of the impact of their activities in the digital environment" (A9), "critically evaluate them and, thanks to them, can lead to the right results." (S1) Critical thinking acts in the role of a reflection of one's existence in the online environment, as a certain corrective and instruction.

At the same time, it applies to the evaluation and retrieval of information "manages to approach information on the Internet critically, distinguish between misinformation and fake news" (A9), "such a person should be able to search for information and use critical thinking" (S1), "he should be able to look at information critically and be able to find the necessary information" (S0). The reason is an epistemic turn or a new situation in the field of cognitive theory: "at the same time, it has a dose of critical thinking/thinking that it can respond to a large amount of data that is all around us. In times of information boom, he needs to be able to filter and verify information from multiple sources." (A9) Critical thinking is a response to an environment that is revealed through information interactions and, at the same time, requires a specific process of cognition.

\section{Discussion}

The students' statements show that cyberspace is a real space where movement or orientation can occur. Looking at Johnson and Lakoff's (1983) definition of spatial metaphors, we see an identical thought structure. It is impossible to decide at this point whether to lean more towards a pragmatist conception of the social construction of reality in the interpretation of cyberspace (Berger \& Luckmann, 1966). The students' responses are such that both aspects apply. From pragmatism, the dimension of structuring activities and tools to be able to work effectively with them in cyberspace; from social constructivism, it is possible to see a strong influence of the cultural climate on the grasp of important topics and issues, as well as some critical insight into the current state of cyberspace and its processes.

Both of these approaches can be seen in the answers that have been analysed. It can even be said that information retrieval and evaluation is an information interaction (Marchionini, 2008; Shedroff, 1999) that leads to the social construction of reality.

Consistent with both social constructivism and pragmatism, students reject the concept of an objectivist grasp of truth arising outside of social interaction but at the same time emphasize the necessity of the truth claim (Kvale, 1995, Tuomela \& Balzer, 2002). In any case, research has refuted Cohen's (2007) view that cyberspace is not a space.

A precise topic in the research was the use of technology. Staying in an online environment leads to higher work efficiency, the ability to solve problems effectively. This topic is systematically analysed in the literature in many sub-facets - from education (Giatman, 2019) to business (Hendayani \& Febrianta, 2020). At the same time, however, a discourse can be found in the literature emphasizing the paradox of productivity, i.e., the fact that technology itself or the technological environment does not automatically lead to greater efficiency (Anderson et al., 2003; Brynjolfsson, 1993; Van Ark, 2016; Yorukoglu, 1998).

Students' responses indicate that technology is a source of some effectiveness for them. A successful stay in the cyber world is linked to the skill and ability to use tools and technology meaningfully, ethically, and safely. Technology is something that brings benefits, and is, therefore, some distance from the productivity paradox to the idea of productivity. This productivity can be learned, students say.

Kolko et al. (2013) described cyberspace as an environment composed of zeros and ones, as a discrete environment of binary oppositional structures. However, this argument for why cyberspace is not a real space is false because it does not match the students' experience. Instead, students emphasize the absence of boundaries between environments, interactions and 
activities, and the competencies we need in one environment or the other. Students' accounts are much closer to what Floridi $(2013,2014)$ refers to as an infosphere integrating online and offline environments than to the discrete world of ones and zeros. Life takes place in a continuum of these two forms of space, interconnected through informational interactions. Cyberspace is a place where living people with a particular cultural, physical, value enter. Here, too, students and Floridi (2011) agree. The nature of cyberspace in terms of its separation and structuring (for students) does not match the notion in Kolko et al. (2013) or Cohen (2007) but is close to Floridi's conception.

A phenomenon that could be described as a crisis of knowledge appears to be crucial for students in research (Beerdsen, 2020; Hopf et al., 2019; Kasper, 2021). This is because the online environment fundamentally changes the distribution of information and information resources (Gibson \& Martin, 2019; Saunders, 2017), enclosing users in filter bubbles (Yang et al., 2017; Kostyrev, 2020).), which change their information horizons (Syn et al., 2017). However, if reality is constructed socially, which is the discourse the research has subscribed to (Kalinkin, 2015), this epistemic barrier changes and distorts the possibility of getting to know actors in the infosphere. Suppose orientation was a basic metaphor referring to the ability to handle movement in cyberspace. In that case, the crisis of knowledge points to a severe problem that students in research are well aware of.

In student testimonies, this aspect is associated with two phenomena. Students stress the importance of critical thinking as a primary epistemic tool. It allows them to recognise truth from falsehood, manipulation, and the efforts of others to limit their freedom of orientation and movement in the cyber world. Critical thinking is not just thinking but a tool of cognition in a complicated and fragmented world. The second level is related to reflection on disinformation - students realise that the space in which they live, think, encounter others, and get information shapes their perceptions of and responses to the world. At the same time, this image, this social construction, is deliberately altered and reshaped; cyberspace is a space of deception and disinformation with which students must cope. Knowing in this context does not mean seeing but critically recognising what is true.

In response to the crisis of knowledge and misinformation (Allcott et al., 2019; Zimmermann \& Kohring, 2018), they emphasise the role of critical thinking (Changwong et al., 2018; Cáceres et al., 2020). The way they think about it is similar to Descartes' scepticism (Brown, 2013; Suzuki, 2012), which has also evolved in response to uncertainty about what knowledge is. Critical thinking and information literacy are both often interrelated concepts (Albitz, 2007; Goodsett, 2014, Siu-cheung 2020) and are associated with the idea of social justice and a specific remedy for the world (Oyediran-Tidings et al., 2019). This approach corresponds well to how students think about the issue.

\section{Conclusions and Implications}

The research of metaphors in students has yielded several results essential for further pedagogical research and practice. Cyberspace is a space in which students construct their social worlds, their knowledge and ties to others. The discussion of the reality or unreality of cyberspace is meaningless. The students themselves realise that it is not a separate space or world but a part of a particular epistemic field in which they perform specific activities. This entails requirements for their competence (digital competence, information literacy, etc.). There is a different structuring of knowledge in this space than in a purely physical space, which can be an exciting point for designing various educational activities.

The second essential point is that students are experiencing a crisis of knowledge in this space. They are entering the post-facto age, the loss of certainties of solid modernity is associated with the growing importance of cyberspace. It is necessary to look for ways to grasp

$\mid$\begin{tabular}{l} 
PROBLEMS \\
OF EDUCATION \\
IN THE 21 $1^{\text {st }}$ CENTURY \\
Vol. 79, No. 6, 2021 \\
\hline 851
\end{tabular} 
Michal ČERNÝ. Cyberspace as a space: Analysis of metaphorical statements of university students

PROBLEMS

OF EDUCATION

IN THE $21^{\text {st }}$ CENTURY Vol. 79, No. 6,202

852

the structure of truth and truthfulness again because purely school knowledge and skills are not sufficient equipment for being in a world that is changing dynamically and in which relevant information is mixed with the unbelievable.

Students are thus in a paradoxical situation. On the one hand, they perceive cyberspace as a natural space to realise their learning, behaviour and actions. It is a space constituted by information interactions, but at the same time does not find that this information will be genuinely true, that the world that students create will not collapse at some point. The increasing implementation of technologies in education is, therefore, an inevitable and essential act. However, it will necessarily be associated with a growing emphasis on information literacy, digital competencies and critical thinking, which students perceive as fundamental tools for mastering this natural space.

At the same time, the study confirmed that pragmatic approaches emphasising the influence of the environment on the structure of meanings and activity as a means of cognition and formation of experience represent a practical philosophical and methodological approach to analysing how students experience their being in cyberspace connected to physical space and forming one functional continuum.

\section{Acknowledgements}

The research was done written thanks to the support of TA CR within the project Platform for knowledge transfer: information literacy for high school students in an open mash-up virtual learning environment (TL02000040).

\section{References}

Adams, P. C. (1997). Cyberspace and virtual places. Geographical Review, 87(2), 155-171. https://doi.org/10.1111/j.1931-0846.1997.tb00069.x

Albitz, R. S. (2007). The what and who of information literacy and critical thinking in higher education. portal: Libraries and the Academy, 7(1), 97-109. https://doi.org/10.1353/pla.2007.0000

Allcott, H., Gentzkow, M., \& Yu, C. (2019). Trends in the diffusion of misinformation on social media. Research \& Politics, 6(2), 2053168019848554. https://doi.org/10.1177/2053168019848554

Anderson, M. C., Banker, R. D., \& Ravindran, S. (2003). The new productivity paradox. Communications of the ACM, 46(3), 91-94. https://doi.org/10.1145/636772.636776

Arrosagaray, M., González-Peiteado, M., Pino-Juste, M., \& Rodríguez-López, B. (2019). A comparative study of Spanish adult students' attitudes to ICT in classroom, blended and distance language learning modes. Computers \& Education, 134, 31-40. https://doi.org/10.1016/j.compedu.2019.01.016

Bailey, R. (2003). Conceptual metaphor, language, literature and pedagogy. Journal of Language and Learning, 1(2), 59-72.

Beerdsen, E. (2020). Litigation Science after the knowledge crisis. Cornell Law Review, 106, 529-590. https://doi.org/10.2139/ssrn.3674258

Berger, P. L. \& Luckmann, T. (1966). The social construction of reality: A treatise in the sociology of knowledge. Anchor.

Betz, D. J. (2017). Cyberspace and the state: Towards a strategy for cyber-power. Routledge.

Boehlefeld, S. P. (1996). Doing the right thing: Ethical cyberspace research. The Information Society, 12(2), 141-152. https://doi.org/10.1080/713856136

Brown, D. (2013). Descartes and content scepticism (pp. 25-42). Cambridge University. https://doi.org/10.1017/cbo9781139030731.005

Brynjolfsson, E. (1993). The productivity paradox of information technology. Communications of the ACM, 36(12), 66-77. https://doi.org/10.1145/163298.163309

Cáceres, M., Nussbaum, M., \& Ortiz, J. (2020). Integrating critical thinking into the classroom: A teacher's perspective. Thinking Skills and Creativity, 37, Article 100674. https://doi.org/10.1016/j.tsc.2020.100674 
Carretero, S., Vuorikari, R., \& Punie, Y. (2017). DigComp 2.1. The digital competence framework for citizens. With eight proficiency levels and examples of use. Publications Office of the European IN THE $21^{\text {st }}$ CENTURY Vol. 79, No. 6, 2021 Union. https://doi.org/10.2760/38842

Carter Jr, R. A., Rice, M., Yang, S., \& Jackson, H. A. (2020). Self-regulated learning in online learning environments: strategies for remote learning. Information and Learning Sciences, 121 (5/6), 321329. https://doi.org/10.1108/ils-04-2020-0114

Casasanto, D. (2009). When is a linguistic metaphor a conceptual metaphor. New Directions in Cognitive Linguistics, 24, 127-145. https://doi.org/10.1075/hcp.24.11cas

Cohen, J. E. (2007). Cyberspace as/and space. Columbia Law Review, 107(1), 210-256.

Concannon, K. (1998). The contemporary space of the border: Gloria Anzaldua's Borderlands and William Gibson's Neuromancer. Textual Practice, 12(3), 429-442.

Coulson, S., \& Cánovas, C. P. (2009). Understanding timelines: Conceptual metaphor and conceptual integration. Cognitive Semiotics, 5(1-2), 198-219.

Černý, M. (2020). Cyberspace as a metaphor of being online or a particular form of space organization? Czech-Polish Historical and Pedagogical Journal, 12/2, 5365. https://doi.org/10.5817/cphpj-2020-021

Daane, A. R., Haglund, J., Robertson, A. D., Close, H. G., \& Scherr, R. E. (2018). The pedagogical value of conceptual metaphor for secondary science teachers. Science Education, 102(5), 1051-1076. https://doi.org/10.1515/cogsem.2009.5.12.198

de Varela, Y. (2018). Cyberspace as potential space. In Psychoanalysis Online 2 (pp. 233-238). Routledge. https://doi.org/10.4324/9780429478840-18

Dodge, M., \& Kitchin, R. (2003). Mapping cyberspace. Routledge.

Ellis, D., Oldridge, R., \& Vasconcelos, A. (2004). Community and virtual community. Annual Review of Information Science and Technology, 38(1), 145-186. https://doi.org/10.1002/aris.1440380104

Fábián, G. (2013). The application of improved metaphor analysis in education research. Procedia-Social and Behavioral Sciences, 93, 1025-1029. https://doi.org/10.1016/j.sbspro.2013.09.323

Fernback, J., \& Thompson, B. (1995). Virtual communities: Abort, retry, failure?. https://www.rheingold. com/texts/techpolitix/VCcivil.html

Floridi, L. (2011). The construction of personal identities Online. Minds And Machines, 21(4), 477-479. https://doi.org/10.1007/s11023-011-9254-y.

Floridi, L. (2013). The philosophy of information. Oxford University.

Floridi, L. (2014). The fourth revolution: How the infosphere is reshaping human reality. Oxford University.

Furió, D., Juan, M. C., Seguí, I., \& Vivó, R. (2015). Mobile learning vs. traditional classroom lessons: a comparative study. Journal of Computer Assisted Learning, 31(3), 189-201. https://doi.org/10.1111/jcal.12071

Gálik, S. (2017). Influence of cyberspace on changes in contemporary education. Communication Today, 8(1), 30-39. https://doi.org/10.5593/sgemsocial2017/41/s16.025

Gao, C., Guo, Q., Jiang, D., Wang, Z., Fang, C., \& Hao, M. (2019). Theoretical basis and technical methods of cyberspace geography. Journal of Geographical Sciences, 29(12), 1949-1964. https://doi.org/10.1007/s11442-019-1698-7

Ghasemi Varjani Iran, T. (2019). Description and analysis of the current situation of religious education in cyberspace. Journal of Pure Life, 6(18), 125-153. https://doi.org/025/P-L.2019.2890

Giatman, M., Haq, S., \& Pratama, Y. F. (2019). Effectivity of online learning teaching materials model on innovation course of vocational and technology education. In Journal of Physics: Conference Series (Vol. 1387, No. 1, p. 012131). IOP Publishing. https://doi.org/10.1088/1742$6596 / 1387 / 1 / 012131$

Gibbs, R. W. (2009). Why do some people dislike conceptual metaphor theory? Cognitive Semiotics, 5(12), 14-36. https://doi.org/10.1515/cogsem.2013.5.12.14

Gibson, A. N., \& Martin III, J. D. (2019). Re-situating information poverty: Information marginalization and parents of individuals with disabilities. Journal of the Association for Information Science and Technology, 70(5), 476-487. https://doi.org/10.1002/asi.24128

Gibson, W. (1995). "I don't even have a modem". http://www.josefsson.net/gibson/index.html 
Michal ČERNÝ. Cyberspace as a space: Analysis of metaphorical statements of university students

PROBLEMS

OF EDUCATION IN THE $21^{\text {st }}$ CENTURY Vol. 79, No. 6, 2021

854

Goodsett, M. (2020). Best practices for teaching and assessing critical thinking in information literacy online learning objects. The Journal of Academic Librarianship, 46(5), Article 102163. https://doi.org/10.1016/j.acalib.2020.102163

Haskins, R. (1989). Beyond metaphor: The efficacy of early childhood education. American Psychologist, 44(2), 274. https://doi.org/10.1037/0003-066x.44.2.274

Hattingh, T., van Niekerk, W., Marais, H., \& Geldenhuys, Y. (2020). Engineering student experiences of a remotely accessed, online learning environment. In 2020 IFEES World Engineering Education Forum-Global Engineering Deans Council (WEEF-GEDC) (pp. 1-6). IEEE. https://doi.org/10.1109/weef-gedc49885.2020.9293652

Hendayani, R., \& Febrianta, M. Y. (2020). Technology as a driver to achieve the performance of family businesses supply chain. Journal of Family Business Management 10(4), 361-371. https://doi.org/10.1108/jfbm-10-2019-0070

Holmes, D. L. (Ed.). (1997). Virtual politics: Identity and community in cyberspace. Sage.

Hopf, H., Krief, A., Mehta, G., \& Matlin, S. A. (2019). Fake science and the knowledge crisis: ignorance can be fatal. Royal Society open science, 6(5), 190161. https://doi.org/10.1098/rsos.190161

Horst, H. A., \& Miller, D. (Eds.). (2020). Digital anthropology. Routledge.

Changwong, K., Sukkamart, A., \& Sisan, B. (2018). Critical thinking skill development: Analysis of a new learning management model for Thai high schools. Journal of International Studies, 11(2). https://doi.org/10.14254/2071-8330.2018/11-2/3

Cholifah, P. S., Nuraini, N. L. S., \& Meidina, A. M. (2020, October). Training on development of edutainment-based innovative learning media for teacher professional development. In Proceedings of the 6th International Conference on Education and Technology (ICET 2020), Malang, Indonesia (pp. 467-471). Atlantis Press. https://doi.org/10.2991/assehr.k.201204.090

Johnson, M. (2007). The meaning of the body: Aesthetics of human understanding. University of Chicago Press.

Johnson, M. (2017). Embodied mind, meaning, and reason. University of Chicago Press.

Johnson-Glenberg, M. C., Megowan-Romanowicz, C., Birchfield, D. A., \& Savio-Ramos, C. (2016). Effects of embodied learning and digital platform on the retention of physics content: Centripetal force. Frontiers in Psychology, 7, 1819. https://doi.org/10.3389/fpsyg.2016.01819

Kalinkin, A. (2015). Cyberspace as a component of global social reality. In Sipakova, I. (Eds), Proceedings of the II International conference for young researchers "Young Scholars" Research in the Humanities”, (pp. 97-99). Techno-Décor. https:/www.sgu.ru/sites/default/files/ textdocsfiles/2015/05/20/maket_sb_2015_v_pechat.pdf\#page $=98$

Kasper, D. (2021). Beyond the knowledge crisis: a synthesis framework for socio-environmental studies and guide to social change. Springer Nature. https://doi.org/10.1007/978-3030-48370-8

Kolko, B., Nakamura, L., \& Rodman, G. (Eds.). (2013). Race in cyberspace. Routledge.

Kostyrev, A. (2020). Liberal Democracy: from the Mass Society Broad Universalism toward the Network Society Deep Sovereignty. Sciences of Europe, 60, 19-28. https://cyberleninka.ru/article/n/ liberal-democracy-from-the-mass-society-broad-universalism-toward-the-network-society-deepsovereignty/viewer

Kövecses, Z. (2008). Conceptual metaphor theory: Some criticisms and alternative proposals. Annual Review of Cognitive Linguistics, 6(1), 168-184. https://doi.org/10.1075/arcl.6.08kov

Kövecses, Z. (2016). Conceptual metaphor theory. In The Routledge handbook of metaphor and language (pp. 31-45). Routledge.

Kvale, S. (1995). The social construction of validity. Qualitative Inquiry, 1(1), 19-40. https://doi.org/10.4135/9781412986267.n18

Lakoff, G. (1998). Women, fire, and dangerous things: What categories reveal about the mind. University of Chicago press.

Lakoff, G., \& Johnson, M. (1980). Conceptual metaphor in everyday language. The Journal of Philosophy, 77(8), 453-486. https://doi.org/10.2307/2025464

Lakoff, G., \& Johnson, M. (1980a). The metaphorical nature of the human conceptual system. Cognitive Science 4(2), 195-208. https://doi.org/10.1207/s15516709cog0402_4

Lakoff, G., \& Johnson, M. (1983). Metaphors we live by. University of Chicago.

Landau, M. J. (2016). Conceptual metaphor in social psychology: The poetics of everyday life. Routledge. 
Lasfeto, D., \& Ulfa, S. (2020). The relationship between self-directed learning and students' social interaction in online learning environment. Journal of E-learning and Knowledge Society, 16(2), 34-41. https://doi.org/10.20368/1971-8829/1135078

Leino, A. L., \& Drakenberg, M. (1993). Metaphor: an educational perspective. Research Bulletin 84. https://files.eric.ed.gov/fulltext/ED364912.pdf

Lemley, M. A. (2003). Place and cyberspace. California Law Review, 91 (2), 521-542. https://doi.org/10.31235/osf.io/bjzw9

Lessig, L. (1996). The zones of cyberspace. Stanford Law Review, 48 (5), 1403-1411. https://doi.org/10.2307/1229391

Lindgren, R., Tscholl, M., Wang, S., \& Johnson, E. (2016). Enhancing learning and engagement through embodied interaction within a mixed reality simulation. Computers \& Education, 95, 174-187. https://doi.org/10.1016/j.compedu.2016.01.001

Lynch, H. L., \& Fisher-Ari, T. R. (2017). Metaphor as pedagogy in teacher education. Teaching and Teacher Education, 66, 195-203. https://doi.org/10.1016/j.tate.2017.03.021

Marchionini, G. (2008). Human-information interaction research and development. Library \& Information Science Research, 30(3), 165-174. https://doi.org/10.1016/j.lisr.2008.07.001

Marres, N. (2017). Digital sociology: The reinvention of social research. John Wiley \& Sons.

Mayer, M., Martino, L., Mazurier, P., \& Tzvetkova, G. (2014). How would you define Cyberspace. First Draft Pisa. https://d1wqtxts1xzle7.cloudfront.net/33741778/Cyberspace_Definition-libre-withcover-page-v2.pdf

Mazzolini, M., \& Maddison, S. (2007). When to jump in: The role of the instructor in online discussion forums. Computers \& Education, 49(2), 193-213. https://doi.org/10.1016/j.compedu.2005.06.011

Murthy, D. (2008). Digital ethnography: An examination of the use of new technologies for social research. Sociology, 42(5), 837-855. https://doi.org/10.1177/0038038508094565

Ning, H., Ye, X., Bouras, M. A., Wei, D., \& Daneshmand, M. (2018). General cyberspace: Cyberspace and cyber-enabled spaces. IEEE Internet of Things Journal, 5(3), 18431856. https://doi.org/10.1109/jiot.2018.2815535

Nyinkeu, N. D., Anye, D., Kwedeu, L., \& Buttler, W. (2018). Cyber Education outside the Cyberspace: The Case of the Catholic University Institute of Buea. International Journal of Technology in Teaching and Learning, 14(2), 90-101. https://files.eric.ed.gov/fulltext/EJ1211986.pdf

O'Connor, H., \& Madge, C. (2003). "Focus groups in cyberspace": Using the Internet for qualitative research. Qualitative Market Research: An International Journal 6(2), 133143. https://doi.org/10.1108/13522750310470190

Okada, A., \& Sheehy, K. (2020, December). Factors and recommendations to support students' enjoyment of online learning with fun: A mixed method study during COVID-19. In Frontiers in Education (Vol. 5, No. 1). https://doi.org/10.3389/feduc.2020.584351

Olson, K. K. (2005). Cyberspace as place and the limits of metaphor. Convergence, 11(1), 10-18. https://doi.org/10.1177/135485650501100102

Ottis, R., \& Lorents, P. (2010). Cyberspace: Definition and implications. In International Conference on Cyber Warfare and Security (p. 267). Academic Conferences International Limited.

Oyediran-Tidings, S. O., Ondari-Okemwa, E. M., \& Nekhwevha, F. H. (2019). Information needs and constraints of access to educational information in the Fort Beaufort Education District. South African Journal of Education, 39(1). https://doi.org/10.15700/saje.v39ns2a1652

Palmárová, V., \& Lovászová, G. (2012). Mobile technology used in an adventurous outdoor learning activity: a case study. Problems of Education in the 21st Century, 44, 64-71. http://www. scientiasocialis.lt/pec/node/files/pdf/vol44/64-71.Palmarova_Vol.44.pdf

Pienimäki, M., Kinnula, M., \& Iivari, N. (2021). Finding fun in non-formal technology education. International Journal of Child-Computer Interaction, 29, Article 100283, 1-13.

Pink, S., Horst, H., Postill, J., Hjorth, L., Lewis, T., \& Tacchi, J. (2015). Digital ethnography: Principles and practice. Sage.

Punday, D. (2000). The narrative construction of cyberspace: Reading Neuromancer, reading cyberspace debates. College English, 63(2), 194-213. https://doi.org/10.2307/379040

Rasheed, R. A., Kamsin, A., \& Abdullah, N. A. (2020). Challenges in the online component of blended learning: A systematic review. Computers \& Education, 144, Article 103701, 1-17. https://doi.org/10.1016/j.compedu.2019.103701

$\mid \begin{aligned} & \text { PROBLEMS } \\ & \text { OF EDUCATION } \\ & \text { IN THE 21 } 1^{\text {st }} \text { CENTURY } \\ & \text { Vol. 79, No. 6, } 2021\end{aligned}$

855 
Michal ČERNÝ. Cyberspace as a space: Analysis of metaphorical statements of university students

PROBLEMS

OF EDUCATION

IN THE $21^{\text {st }}$ CENTURY Vol. 79, No. 6,2021

856

Rodriguez, M. C., Ooms, A., \& Montañez, M. (2008). Students' Perceptions of Online-Learning Quality Given Comfort, Motivation, Satisfaction, and Experience. Journal of Interactive Online Learning, $7(2), 105-125$.

Ryan, M. L. (2015). Narrative as virtual reality 2: Revisiting immersion and interactivity in literature and electronic media (Vol. 2). John Hopkins University.

Saracco, R. (2019). Digital twins: Bridging physical space and cyberspace. Computer, 52(12), 58-64. https://doi.org/10.1109/mc.2019.2942803

Saunders, L. (2017). Connecting information literacy and social justice: Why and how. Communications in Information Literacy, 11(1), 15. https://doi.org/10.15760/comminfolit.2017.11.1.47

Selwyn, N. (2019). What is digital sociology?. John Wiley \& Sons.

Shedroff, N. (1999). Information interaction design: A unified field theory of design. Information Design, 267-292. http://papers.cumincad.org/data/works/att/3fce.content.pdf

Sherron, G. T., \& Boettcher, J. V. (1997). Distance learning: The shift to interactivity (Vol. 17). Cause.

Siu-cheung, K. (2014). Developing information literacy and critical thinking skills through domain knowledge learning in digital classrooms: An experience of practicing flipped classroom strategy. Computers \& Education, 78, 160-173. https://doi.org/10.1016/j.compedu.2014.05.009

Smart, K. L., \& Cappel, J. J. (2006). Students' perceptions of online learning: A comparative study. Journal of Information Technology Education: Research, 5(1), 201-219. https://doi.org/10.2139/ssrn.3524610

Smith, B. G. (2010). E-learning technologies: A comparative study of adult learners enrolled on blended and online campuses engaging in a virtual classroom (Doctoral dissertation, Capella University).

Snape, P. (2011). Quality learning for technology education: An effective approach to target achievement and deeper learning. Problems of Education in the 21st Century, 38, 95-104. http://www. scientiasocialis.lt/pec/files/pdf/vol38/95-104.Snape_Vol.38.pdf

Soffer, T., \& Nachmias, R. (2018). Effectiveness of learning in online academic courses compared with face-to-face courses in higher education. Journal of Computer Assisted Learning, 34(5), 534-543. https://doi.org/10.1111/jcal.12258

Stokrocki, M. (2007). Art education avatars in cyberspace: Research in computer-based technology and visual arts education. In Bresler, L. (Eds.), International handbook of research in arts education (pp. 1361-1379). Springer.

Stratton, J. (2013). Cyberspace and the globalization of culture. In Porter, D. (Eds.), Internet culture (pp. 253-275). Routledge. https://doi.org/10.4324/9780203948873-15

Suzuki, F. (2012). The Cogito Proposition of Descartes and characteristics of his ego theory. Bulletin of Aichi University of Education 61, pp. 73-80. https://core.ac.uk/reader/147573560

Syn, S. Y., Sinn, D., \& Kim, S. (2017). College students' personal information management: From a perspective of information horizon theory. Proceedings of the Association for Information Science and Technology, 54(1), 808-810. https://doi.org/10.1002/pra2.2017.14505401166

Švec, V. (2004) Experience of Student Teachers as a Source of their Pedagogical Knowledge. The New Educational Review. 4(3-4), p. 57-69.

Švec, V. et al. (2016) Becoming a teacher: The dance between tacit and explicit knowledge. Masarykova univerzita. https://doi.org/10.5817/CZ.MUNI.M210-8605-2017

Taddeo, M. (2018). The limits of deterrence theory in cyberspace. Philosophy \& Technology, 31(3), 339355. https://doi.org/10.1007/s13347-017-0290-2

Tang, Y., \& Hew, K. F. (2020). Does mobile instant messaging facilitate social presence in online communication? A two-stage study of higher education students. International Journal of Educational Technology in Higher Education, 17(1), 1-17. https://doi.org/10.1186/s41239-02000188-0

Tuomela, R., \& Balzer, W. (2002). Collective acceptance and collective attitudes: on the social construction of social reality. Fact and fiction in economics: Models, realism and social construction, 269-284. https://doi.org/10.1017/cbo9780511493317.014

Van Ark, B. (2016). The productivity paradox of the new digital economy. International Productivity Monitor, (31), 3.

Varis, P. (2016). Digital ethnography. In Georgakopoulou, A. \& Spilioti, T. (Eds.), The Routledge handbook of language and digital communication, (pp. 55-68). Routledge. 
Wah, L. L. (2007). Development of multimedia learning resources for children with learning disabilities in an undergraduate special education technology course. Malaysian Education Dean's Council (MEDC), 1, 29-36.

Walmsley, D. J. (2000). Community, place and cyberspace. Australian Geographer, 31(1), 5-19. https://doi.org/10.1080/00049180093501

Walsh,K.R., \& Pawlowski, S.D.(2002). Virtual reality:Atechnology inneed ofIS research.Communications of the Association for Information Systems, 8(1), 20. https://doi.org/10.17705/1 cais.00820

Wolfe, C. R. (2001). Plant a tree in cyberspace: Metaphor and analogy as design elements in web-based learning environments. CyberPsychology \& Behavior, 4(1), 6776. https://doi.org/10.1089/10949310151088415

Yang, J., Barnidge, M., \& Rojas, H. (2017). The politics of "Unfriending": User filtration in response to political disagreement on social media. Computers in Human Behavior, 70, $22-$ 29. https://doi.org/10.1016/j.chb.2016.12.079

Yorukoglu, M. (1998). The information technology productivity paradox. Review of Economic Dynamics, 1(2), 551-592. https://doi.org/10.1006/redy.1998.0016

Zimmermann, F., \& Kohring, M. (2018). „Fake News “als aktuelle Desinformation. Systematische Bestimmung eines heterogenen Begriffs. M\&K Medien \& Kommunikationswissenschaft, 66(4), 526-541. https://doi.org/10.5771/1615-634x-2018-4-526

Received: September 01, 2021

Accepted: November 29, 2021

PROBLEMS

OF EDUCATION

IN THE $21^{\text {st }}$ CENTURY

Vol. 79, No. 6, 2021

857

Cite as: Černý, M. (2021). Cyberspace as a space: Analysis of metaphorical statements of university students. Problems of Education in the $21^{\text {st }}$ Century, 79(6), 838-857. https://doi.org/10.33225/pec/21.79.838

Michal Černý

Senior Researcher, Department of Information and Library Studies, Faculty of Arts \& Department of Social Education, Faculty of Education at Masaryk University, Czech Republic.

E-mail: mcerny@phil.muni.cz

Website: https://is.muni.cz/osoba/268947?lang=en

ORCID: https://orcid.org/0000-0003-0384-8974 